\title{
Die vyfvoudig versterkte vertellersfunksie in die dagboeke van Anne Frank
}

\author{
Chrissie Reinecke \& Jacques van der Elst \\ Departement Afrikaans en Nederlands \\ Potchefstroomse Universiteit vir $\mathrm{CHO}$ \\ POTCHEFSTROOM
}

\begin{abstract}
A five-fold strengthened narrative function in the diaries of Anne Frank

In assuming that the total communication situation in the true diary has a character of its own, it is suggested that the narrative situation is studied, on the one hand, from the viewpoint of the autobiographical contract claiming a bond of identity between the real author, the I-narrator and the I-persona, and on the other hand from the poststructuralistic view asserting that these instances are not identical to one another and that the implicit author should be duly recognised. A close textual analysis of the narrative situation in the original diaries of Anne Frank leads to our ideniffying five instances strengthening the narrative function - the real author, the Inarrator, the I-persona, the implicit and the explicit author. While these instances can be distinguished from one onother, the bond of identity between them is so tight that the textual construction is a testimony to reality. The five-fold narrative corpus functioning in the diaries persuasively conveys a message of truth. A remarkable characteristic of the narrative situation is the persistent explicitising of the implicit author, which can be seen as a concretisation of the intention of truth and sincerity posed by the autobiographical contract.
\end{abstract}

\section{Oriëntering}

In 1994 - die vyftigste herdenkingsjaar van die inhegtenisname van die agt Jode wat twee jaar lank in Het Achterhuis geskuil het - val die soeklig oral in die wêreld weer op die dagboeke van Anne Frank. Teen die agtergrond van die huidige belangstelling in lewensverhale soos die outobiografiel, vra die oorweldigende resepsie van die dagboeke van Anne Frank oor soveel jare opnuut aandag vir die dagboek. Hoewel Brolsma (1982:16) aandui dat daar heelwat meningsverskil oor die literêre waarde van die dagboek bestaan, kom Severijnen $(1989: 67,78)$ tot die gevolgtrekking dat die modernistiese kode van die dagboek

$1 \quad$ Vergelyk Jongeneel (1989) wat 'n kongresbundel oor dic outobiografic is en Jacobs (1991a). 
of die selfportret die optimale vorm bied om die eie lewe te beskryf. Ook Musarra-Schroeder (1983:70 en 1989:48-49) wys telkens op die moderne skrywer se voorkeur vir die dagboek. Sy is oortuig dat die keuse deur 'n waarheidsdrang gemotiveer word

Oor die Nederlandse woord dagboek skryf Brolsma (1982:5) dat dit waarskynlik in die sestiende of sewentiende eeu ontstaan het, in dieselfde tyd as die Duitse Tagebuch en die Engelse daybook - benaminge wat nou deur diary of die sinoniem journal vervang is. In Afrikaans leef die benaming dagboek voort. Getrou aan die etimologiese kern van die woord dagboek én van joernaal, naamlik die Latynse dies wat "dag" beteken, is die enigste vaste kenmerk van die egte dagboek met sy andersins losse en fragmentariese weergawe van gebeurtenisse, indrukke en gevoelens wat die outeur self beleef het, die min of meer daaglikse vertelling wat 'n gelyktydige of kwasigelyktydige tydstruktuur tot gevolg het. Vir Weintraub (1989:13) is "de heiligheid van elk moment" en die afgerondheid van die vertelling van elke dag 'n sine qua non in die dagboek. Dit moet beklemtoon word dat die aandag hier op die egte dagboek toegespits is en nie op pseudodagboekgenres soos die dagboekroman of die briefroman nie. 'n Gemeenskaplike faktor in Weintraub se afbakening van verwante vorme van lewensverhale (Weintraub, 1989:11-13), naamlik die outobiografie, die res gestae, die memoires, die selfportret en die outobibliografie, is die vraag in watter mate die genres die eie lewe so beskryf dat die werklike lewe in herinnering geroep word.

$\mathrm{Na}$ aanleiding van bogenoemde bespreking word van die hipotese uitgegaan dat 'n eiesoortige kommunikasiesituasie in die egte dagboek funksioneer. Hierin speel werklikheidsgetrouheid, waarvan die tydstruktuur 'n belangrike manifestasie is, "n belangrike rol. Die doel is om vas te stel hoe dié kommunikasiesituasie in die dagboeke van Anne Frank gerealiseer word. Onder die kommunikasiesituasie, wat primêr of sekondêr kan wees, word verstaan dat 'n vertelinstansie of -instansies 'n boodskap aan 'n toehoorderinstansie of -instansies oordra, sodat daar van 'n vertel- en 'n toehoordersituasie sprake is. In hierdie artikel word op die vertelsituasie in die dagboeke van Anne Frank gekonsentreer. Die vertelsituasie hou in dat 'n tekstuele verteller optree en dat die verteller onder andere in 'n bepaalde verhouding staan tot ander instansies wat die vertellersfunksie kan versterk. Moontlike instansies is 'n persoon in die teks, die werklike outeur en die implisiete outeur. Op grond van die aanname dat hierdie instansies die vertellersfunksie versterk, word hulle in die artikel vertelinstansies genoem. Daar word dus 'n ruimer inhoud aan die term geheg as byvoorbeeld Bal (1985:125) se afbakening dat die vertelinstansie "de taaltekens uit het verhaal betekenen". Hoewel sake soos fokalisasie 'n belangrike aspek van die vertelsituasie is, val dit buite die bestek van die artikel. Hoe die toehoorder- 
situasie die kommunikasiesituasie in die dagboeke voltooi, is reeds elders bespreek. $^{2}$

\section{Benaderings tot die dagboek}

Afgesien van die tradisionele benadering tot die dagboek word ook modeme literatuurbeskouings in 'n verwysingsraamwerk opgeneem.

\subsection{Tradisionele benadering}

Uit Brolsma (1982) se oorsig oor die geskiedenis van die dagboek in Europa blyk dit dat die oorsprong van die dagboek in daaglikse objektiewe verslae oor die gebeurtenisse van die spesifieke dag gevind kan word, van koopliede se aantekeninge oor hulle daaglikse wedervaringe tot die res gestae of hofkronieke van die Romeine. 'n Soeke na identiteit begin by die Grieke onder die motto "ken uself", terwyl Seneca se Briewe aan Lucillius, waarin die beeld van iemand wat homself voor 'n regter aankla, vir selfondersoek gebrnik word, een van die belangrikste voorbeelde vir moderne dagboekskrywers word. Intense gevoelservarings tree sterk op die voorgrond in die massas sonderegisters en biegdagboeke wat vanaf die sestiende tot die laat-agtiende eeu geskryf word, terwyl selfondersoek en eenwording met God belangrike temas is. Brolsma (1982:13) en Fontijn (1992:21) stem saam dat die bewuswording van individualiteit in die agtiende eeu selfbewustheid versterk en die regte klimaat vir die ontstaan van die egte dagboek skep. In die twintigste eeu leef die spanning tussen die intieme, persoonlike en die rapportageagtige, onpersoonlike dagboek voort. Dagboeke word geklassifiseer op grond van die skrywer of die tema, byvoorbeeld tiener- of oorlogsdagboeke.

Aspekte uit die oorsig, soos die wisseling tussen subjektiwiteit en objektiwiteit, die soeke na 'n eie identiteit en intense gevoelservarings raak die vertelsituasie, maar is nie voldoende om die eiesoortigheid van dié van die egte dagboek te beskryf nie

\subsection{Die dagboek as 'n outobiografiese skryfwyse}

'n Insig in die vertelsituasie kan verkry word as die dagboek as 'n outobiografiese skryfwyse benader word. Dié word soos volg deur Musarra-Schroeder (1989:4142) gedefinieer:

Ik versta hieronder de strategieën, die het subject gebruikt on door zelfbespiegeling ziclı een idee van eigen persoonlijkheid te vormen en door

2 Vergelyk Reinecke en Van der Elst (1995:92-105). 
middel van het schrijven een beeld ervan te geven. De doelstelling van de autobiografie kan in de termen van James Olney gezien worden als 'a discovery, a creation, and an imitation of the self, waarbij autos (zelf) en graphein (schrijven) soms meer dan bios (leven) benadrukt worden.

Hierdie beskouing is gebou op die aanname dat die outobiografiese skrywe 'n taalkategorie is en as sodanig kan dit sowel kontekstueel-pragmaties as diskursief-tipologies omskryf word. Volgens eersgenoemde benadering word naas die outobiografie in engere sin ook die dagboek, die selfportret en die brief as vorme van outobiografiese skrywe geakkommodeer. Die tweede ruimer benadering sluit naas die genoemde genres ook die pseudo-outobiografiese genres soos die herinneringsroman, die dagboek- en die briefroman en die moderne ekverhaal in die teenwoordige tyd in.

Die kontekstueel-pragmatiese omskrywing word deur Severijnen (1989:65) na Elisabeth Bruss teruggevoer wat op grond van die taalhandelingsteorie van Searle drie reëls vir die outobiografiese skryfwyse geformuleer het: 'n drieledige identiteitsverhouding tussen die ek-verteller, die ek-figuur en die werklike outeur, 'n waarheidsintensie en opregtheid. Vir Philippe Lejeune sluit die skrywer met dié tekens 'n outobiografiese verdrag of pact met die lesers, verduidelik MusarraSchroeder (1989:42) en Jacobs (1991b:i). Die aanwesigheid van die verdrag word eerstens buite die eintlike teks opgemerk - op die titelpagina (die titel van die boek en die naam van die outeur, wat met dié van die persoon waaroor daar vertel word, ooreenstem), op die agterflap van die stofomslag, in voor- en nawoorde, maar ook in die teks self. Die outobiograaf verduidelik en lewer kommentaar op sy doelstelling en dit wat daaruit voortvloei én verduidelik sy strewe na waarheid en opregtheid.

Volgens die diskursief-tipologiese omskrywing wat Musarra-Schroeder (1989:43) met behulp van begrippe van Emile Benveniste formuleer, word die outobiografiese van die nie-outobiografiese skryfwyse onderskei deurdat diskoerselemente veral in eersgenoemde skryfwyse en geskiedeniselemente in laasgenoemde die botoon voer. Diskoerselemente waarvan hier sprake is, is die persoonlike voornaamwoorde van die spreeksituasie, naamlik $e k-j y$; die werkwoord in die onvoltooide en die voltooide teenwoordige en die toekomende tyd; aanwysende tyds- en plekaanduidings; performatiewe en modale werkwoorde (ek skryf, ek meen, ek hetwyfel en dergelike); uitdrukkings wat op persoonlike gevoelens betrekking het; ten slotte, metateks in die vorm van besinning oor die skryfproses.

Binne die groep outobiografiese skryfwyses, volgens Musarra-Schroeder (1989:45-49), figureer baie van dié elemente baie sterker in die dagboek, die brief en die selfportret as in die outobiografie, terwyl die verhouding tussen die twee ekke wat deur dieselfde eienaam geïdentifiseer word, van afstandneming in die 
outobiografie tot 'n algehele reduksie in die dagboek wissel. Die afstand word steeds kleiner as daar ' $\mathrm{n}$ identiteitsproblematiek is - 'n belangrike aspek teen die agtergrond van die klassieke identiteitsoeke in die dagboek. 'n Wesentlike verskil tussen die outobiografie en die dagboek word in die tydstruktuur gevind 'n retrospektiewe teenoor 'n gelyktydige of kwasigelyktydige vertelling.

\subsection{Die dagboek en 'n poststrukturalistiese siening}

In 'n reaksie daarteen dat die reël van identiteit in die outobiografiese verdrag daartoe gelei het dat die werklike outeur, die ek-verteller en die ek-figuur in die outobiografiese skryfwyse dikwels as identies aan mekaar beskou word, pleit Coullie (1991:1-8) dat daar nie net tussen hulle onderskei moet word nie, maar dat ook die implisiete outeur, "comprising the norms and values of the text" (Coullie, 1991:4), erken word. Sy grond haar argument op die poststrukturalistiese insig dat identiteit nooit mimeties in die teks gerepresenteer kan word nie, maar slegs gekonstrueer kan word, en wel in subjekposisies wat deur taal en kultuur bepaal word. Afgesien daarvan dat die subjekposisies nooit vas is nie, kan die ek-verteller verskillende subjekposisies in die teks inneem - die ekverteller het dus nie vaste karaktertrekke nie.

Ook vir Briosi (1989:58-59) is die gelykskakeling van outeur en verteller 'n illusie wat uit die outobiografiese ooreenkoms ontstaan het en wat nie kan bestaan sonder om tegelykertyd 'n denkbeeldige ooreenkoms te word nie. Gevolglik is die sogenaamde gelykskakeling van outeur en verteller altyd aanwesig, maar terselfdertyd altyd denkbeeldig. Wesentlik is die ooreenkoms dus slegs op hulle name van toepassing. Ook die verteller vereenselwig hom met die persona, maar nooit heeltemal nie.

\subsection{Werklikheidsgetrouheid en waarheid}

Vir die doel van die artikel word tussen werklikheidsgetrouheid en waarheid onderskei. Onder eersgenoemde word min of meer geïsoleerde gegewens verstaan wat histories bevredigend gekonstrueer kan word, en onder laasgenoemde die totale aanbod van die sin en samehang van die gegewens.

Die agterhaalbaarheid van die werklikheid en die waarheid word as problematies ervaar. Omdat die werklikheid slegs deur die medium van taal en kultuur - wat inkonsekwent en onsamehangend is - toeganklik is, twyfel Coullie (1991:14) of die werklikheid in 'n teks agterhaal kan word. Sy gee egter ook toe dat daar binne 'n maatskappy bepaalde konvensies bestaan wat vir die representasie van die waarheid aanvaar word, byvoorbeeld joernalistieke praktyke, soos die spesifisering van datums en plekke, foto's, weglatings en die gebruik van die prosavorm. Die debat oor die agterhaalbaarheid van die waarheid word telkens aangetref. Vanuit 'n postmodernistiese perspektief wys Briosi (1989:59) daarop 
dat die "objektiewe waarheid" nie meer van die hoogste belang is nie. Gititi (1991:48), daarenteen, redeneer dat 'n werklikheidsgetroue teks die funksie van getuienis kan hê. Die werklike ervaringe wat deur die verteller/protagonis gerepresenteer word, word metonimies omdat die leser sy eie werklike ervaringe daarmee kan identifiseer.

Fontijn (1992:53-55) vestig die aandag daarop dat die waarheidswaarde van geskrifte, veral van dagboeke soos dié van Van Eeden, vanweë die persoonlikheid van die outeur en funksies soos die terapeutiese, problematies kan wees. Aan die ander kant teken Broeksma-Van Capella (1991:71) aan dat Van Eeden juis dinge in sy dagboek geskryf het wat hy andersins nie sou gewaag het om onder vier oë te sê nie. Hierdie aspek hang ten nouste saam met fokalisasie waarop nie in besonderhede ingegaan word nie.

\subsection{Samevatting}

Die vertelsituasie in die dagboek kan vanuit twee standpunte ondersoek word, naamlik dat daar tussen die ek-verteller, die ek-figuur, die implisiete outeur en die werklike outeur in die vertelsituasie onderskei kan word én dat hulle met mekaar geïdentifiseer kan word. Musarra-Schroeder se samevatting van Bruss en Lejeune se aanspraak op die drieledige identiteitsverhouding tussen die ekverteller, die ek-figuur en die werklike outeur is wesentlik 'n aanspraak op werklikheidsgetrouheid. In die lig van die definisie van die implisiete outeur as die totale aanbod van die oortuiging van die teks, beweeg Coullie op die terrein van die waarheid as sy ook die implisiete outeur in die identiteitsargument betrek.

\section{Die DB-teks}

Die oorgelewerde dagboeke van Anne Frank bestaan uit drie verskillende handgeskrewe dagboeke en 'n hele aantal handbeskrewe los velle papier. Verder is daar ook die sogenaamde Verhaaltjeshoek. Vir hierdie navorsing is die uitgawe van die Rijksinstituut voor Oorlogsdocumentatie (1986) uiters geskik (verderaan as DB afgekort), want die teks is so saamgestel dat drie verskillende weergawes van die dagboeke - onderskeidelik met $\mathbf{a}, \mathbf{b}$, en $\mathbf{c}$ in die linkerkantlyn van DB aangedui - parallel onder mekaar op elke bladsy aangebied word. Soms is ook inskrywings uit die Verhaaltjeshoek, met 'n $\mathbf{v}$ aangedui, opgeneem. Die waarde van die DB-uitgawe lê verder in die historiese dokumentasie in die vorm van 'n aantal waardevolle inleidings en voetnote. Op grond hiervan word aanvaar dat die dagboeke soos wat hulle in DB opgeneem is, histories geverifieer is, of in die poststrukturalistiese idioom - dat hulle aanvaarbare konstruksies van die werklikheid is. In die bespreking wat hierna volg, is die aanhalings sover moontlik uit die a-weergawe geneem om so naby moontlik aan die teks van die 
egte dagboek te bly. Waar die a-weergawe ontbreek, is noodwendig van die ander weergawes gebruik gemaak. ${ }^{3}$

Dié artikel moet liefs nie aan die hand van die gepubliseerde Het Achterhuis alleen gelees word nie; laasgenoemde is nie meer 'n egte dagboek nie, maar 'n verwerking van die oorspronklike dagboek in 'n dagboekroman. Van der Stroom (1986a:71) wys daarop dat Anne byvoorbeeld 'n lys van naamsveranderinge opgestel het. Dié is deur die finale redigeerders van Het Achterhuis geïmplemen-

3 Dic ontstaan van dic dagbocke (vgl. Van der Stroom 1986a:69-90) cn dic samestelling van DB (vgl. Van der Stroom, 1986a:189-193) word kortliks verduidelik:

\section{Die a-weergawe}

Dic a-weergawe bestaan uit dic tcks van dic oorspronklike dric handgeskrewe dagboeke van Anne (Van der Stroom, 1986b:189).

Dagboek 1, 'n byna vierkantige poësicalbum met 'n rooi en wit geruitc omslag, wat Anne op haar derticnde verjaarsdag present gekry het, dek dic tydperk 12 Junic tot 5 Desember 1942, terwyl sy in 1943 en 1944 nog cnkele aantekeninge bygevoeg en 'n aantal bladsyc wat onbeskrewe was, benut het (Van der Stroom, 1986a:69).

Dagboek 2, 'n skoolskrif (DB:444a), begin op 22 Desember 1943, meer as 'n jaar na dic laaste inskrywing in 1942 van Dagboek I, cn strck tot 17 April 1944. Tusscnin mót daar een of meer dagbocke verlore gegaan het, is Van der Stroom (1986a:69) se gevolgtrekking.

Dagboek 3 - ook 'n skoolskrif, volgens Van der Stroom (1986a:69) - begin met 'n titclblad (DB:627): "Dagbock van Anne Frank. van 17 April 1944 tot ...". Daar is geen cinddatum nic. Dic laaste inskrywing is 1 Augustus 1944 gedatecr.

\section{Die b-weergawe}

Van der Stroom (1986a:69-70) verduidelik dat die tweede weergawe in Anne se handskrif tot stand gekom het na aanleiding van 'n beroep van dic Minister van Onderwys, Kuns en Wetenskap van dic Nederlandse regering op 28 Maart 1944. Almal wat tydens dic oorlog dagbocke geskryf het, moes hullc geskriftc bewaar. Anne het begin droom om haar dagbock as 'n roman met dic titcl Het Achterhuis uit te gec (DB:594a). Die dagboeke is op los velle papier orgeskryf en is as dic b-weergawe in DB opgencem (Van der Stroom, 1986b:189).

\section{Die c-weergawe}

Dic c-wcergawc bestaan uit dic teks van Het Achterhuis (Van der Stroom, 1986b:189) wat in 1947 onder dic wakende oog van Anne se vader geredigecr en gepubliseer is (Van der Stroom, 1986a:83).

\section{Die v-inskrywings}

Dic Verhaaltjeshoek (dic verkorte titcl vir Verhaaljes, en gebeurtenissen wit Het Achterhuis) is in 1943 en aan dic begin van 1944 deur Annc in 'n kasbock geskryf (Van der Stroom, 1986b:69). In Het Achterhuis is 'n paar verhale uit dic Verhaaltjesboek ingelas. Hicrdic tcksgedecltes word in DB op dic plek van dic a- en b-wecrgawes opgeneem en met ' $\mathrm{n} v$ aangedui (Van der Stroom, 1986b:190). 
teer: "v. Pels" word "v. Daan", "Pfeffer" word "Dussel", "Kleiman" word "Kraler", "Bep" word "Elly", ensovoorts. Verder kom talle teksverskuiwings, stylveranderings en verbeterings van die a- na die b- en c-weergawe voor. In hierdie artikel word die aanhalings uit die dagboeke weergegee net soos wat hulle in die oorspronklike teks voorkom om die karakter van die egte dagboeke te behou. Om dié rede mag byvoorbeeld spelfoute en onreëlmatighede in leestekengebruik voorkom.

\section{Die vertelsituasie in die dagboeke van Anne Frank}

In die dagboeke van Anne Frank domineer 'n kommunikasiesituasie waarin die grootste deel van die boodskap die vorm van briewe aanneem wat deur 'n ekverteller aan 'n jy-toehoorder, Kitty, gerig is. Binne die raamwerk van die artikel word op die vertelsituasie gekonsentreer. Eers word die ek-verteller en die ander instansies wat die vertelfunksie versterk, geïdentifiseer en baie kortliks beskryf; daarna word die verhouding tussen hulle ondersoek.

\subsection{Identifisering van vier vertelinstansies}

Die werklike outeur van die dagboeke van Anne Frank is die werklike persoon Anne Frank. Binne die konteks van die outobiografiese verdrag word dit deur 'n faksimilee van die titelblad van die oorspronklike Dagboek 3 bevestig (DB:627). Die historisiteit van Anne Frank is deeglik deur Paape (1986a, 1986b, 1986c en $1986 \mathrm{~d}$ ) nagevors. Anne is 'n Duits-gebore Jodinnetjie wat as gevolg van die Jodevervolging tydens die Tweede Wêreldoorlog saam met haar ouers, haar suster Margot en 'n aantal ander Jode in Het Achterhuis agter die sakeonderneming te Prinsengracht 263 gaan "skuil". Die ander Jode is die egpaar Van Pels en hul seun Peter en dr. Fritz Pfeffer. Die Jode word versorg deur kollegas van Otto Frank, naamlik Victor Kugler, Johannes Kleiman, Miep en Jan Gies en Bep Voskuyl. Na meer as twee jaar van suksesvolle skuilgaan word die groep van agt Jode op 4 Augustus 1944, kort voor die Bevryding, gearresteer. Anne skryf haar dagboeke hoofsaaklik tydens die skuilperiode.

In hierdie bespreking word onder die ek-verteller eerstens die tekstuele "ik" verstaan. Die ek-verteller wat geen twyfel laat dat sy "alles" so graag wil vertel, word reeds op die buiteblad van die dagboek ondubbelsinnig met die ondertekening van die volgende voomeme geïdentifiseer (DB:197a):

Ik zal hoop ik aan jou van alles kunnen toevertrouwen, zoals ik het nog aan niemand gekund heb, en ik hoop dat je een grote steun voor me zult zijn.

Anne Frank. 12 Junie 1942

Dwarsdeur die dagboek word die leser daaraan herinner dat Anne Frank die ekverteller is. Die inskrywings of die briewe is feitlik deurgaans onderteken: baie 
met "Anne" (DB:45la), ander met "AnneFrank" of "Anne Frank" (DB:293aDB:305a), "je Anne M. Frank" (DB:679a) of selfs met die volle name "Anne Mary Frank" (DB:500a). Met die volgehoue ondertekening van die briewe word die ek-verteller ondubbelsinnig deur die eienaam "Anne Frank" en die verskillende weergawes daarvan geïdentifiseer.

Net soos in die geval van die ek-verteller word onder die ek-figuur ook 'n tekstuele konstruksie verstaan. In die inskrywing van 23 Maart 1944 (DB:576a) kom die volgende mededeling voor: "Nu over mezelf."

Die oorheersende indruk wat die lywige dagboeke op die leser maak, is dat die "over mezelf" tipies van die dagboeke is. Dit word deur die volgende inskrywing bevestig (DB:267a):

Nu ben ik toch weer met mijzelf bezig, maar dat mens, komt ook altijd op de meest intieme ogenblikken. Nu is al mijn plezier er weer af, dáág Kit, groet ze allemaal van mij je

\section{Anne Frank.}

Hoewel die rol van die ek-figuur as verteller baie kleiner en nie so opvallend soos dié van die ek-verteller is nie, is die ek-figuur soms tog die subjek van 'n taaluiting én lewer sy oor 'n reeks opeenvolgende gebeurtenisse verslag, soos in die volgende brief aan Kitty (DB:538a):

Hier zal ik enige briefjes laten volgen die Margot en ik elkaar gister en vanmiddag geschreven hebben, alleen maar voor de lol natuurlijk: ...

Woensdag:

Anne: Gek, hé, mij vallen nachtelijke gebeurtenissen altijd pas veel later in, nu weet ik plotseling dat mijnheer Pfeffer vannacht erg gesnurkt heeft (nu is het Woensdagmiddag kwart voor drie en mijnh. Pf. snurkt weer, daardoor viel het me natuurlijk in) en dat, toen ik op de po moest, ik expres wat meer lawaai maakte om dat ronken op te laten houden.

Verder heb ik ze horen vliegen (letterlijk!), heb van Jacque en J. en na-deoorlog gedroomd en heb me best geamuseerd. $\underline{\text { A. }}$

je Anne M. Frank.

Op grond daarvan dat in navolging van Booth (1982:71-76), Rimmon-Kenan (1983:86) en Coullie (1991:4) onder die implisiete onteur die norme en die waardes van die teks as 'n geheel verstaan word, word aanvaar dat sleutelwoorde (en hulle afleidings of stamwoorde) soos "filosofie", "lewensbeskouing", "teorie", "mening", "opvatting", "beskouing", "beginsels", "standpunt" 'n aanduiding van die funksionering van die implisiete outeur is. Die volgende is 
een van talle voorbeelde (DB:705a)4: "Door deze dingen ben ik er toe gekomen $m$ 'n levensheschouwingen en m'n goed overdachte theorieën nooit aan iemand anders mee te delen dan aan m'n dagboek en een enkele keer aan Margot."

Hoewel die implisiete outeur as 'n dit beskou word, word die dit ook eksplisiet aan 'n eienaam gekoppel (DB:690a):

Hij is een veel meer gesloten natuur dan ik, dat is waar; maar ik weet en nu werkelijk uit de praktijk, (denk aan 'Anne in theorie' dat steeds weer op de proppen komt) dat zelfs de gesloten naturen op hun tijd, net zo hard of nog harder naar een vertrouwde verlangen.

Die norme en waardes in die dagboeke is dus die resultaat van Anne wat besig is om te teoretiseer.

Samevattend kan voorlopig vier moontlike vertelinstansies, naamlik die werklike outeur, die ek-verteller, die ek-figuur én die implisiete outeur in die dagboeke van Anne Frank geidentifiseer en aan 'n enkele eienaam, naamlik "Anne Frank", gekoppel word. Om vas te stel in watter mate die instansies van mekaar onderskei kan word of moontlik identiek aan mekaar is, word die verhouding tussen hulle fyner ondersoek.

\subsection{Die verhouding tussen die vertelinstansies}

Die verhouding tussen die ek-verteller en die ek-figuur kom eerstens aan die beurt, daarna dié tussen die implisiete outeur aan die een kant en die ek-verteller en die ek-figuur aan die ander kant en ten slotte die verhouding tussen die werklike outeur enersyds en die ek-verteller, die ek-figuur en die implisiete outeur andersyds.

\subsubsection{Die ek-verteller en die ek-figuur}

Die klassieke dagboeksoeke na identiteit is onmiskenbaar in die dagboeke van Anne Frank. Die eksplisitering van die soeke word gemanifesteer in die volgehoue spel met die verskillende vorme van die eienaam "Anne Mary Frank" waarmee die inskrywings in die a-weergawe onderteken word - 'n aspek wat verlore gaan in die b- en c-weergawe, waarin al die inskrywings met "je Anne" onderteken word. Anne soek na 'n anker in 'n lewens- en familiegeskiedenis (DB:209a en DB:650a). Sy probeer haarself omlyn in beskrywings van haar fisiese voorkoms (DB:197a, DB:382b, DB:445b en DB:468a), selfs van die heel intiemste dele van haar liggaam (DB:584a), maar ook in die talle foto's wat sy

$4 \quad$ Kursivering in dic aanhalings deur dic outeurs. 
inplak en waarop sy kommentaar lewer (DB:210a, DB:299a en DB:300a). 'n Aspek van haar selfondersoek is die begeerte na helderheid in haar emosioneel verwarde "bakvisziel" (DB:472a) en na 'n oplossing vir die konflik tussen haar innerlike en uiterlike (DB:477a), terwyl die herhaaldelike botsings met die ander inwoners van Het Achterhuis haar aan haar identiteit laat twyfel (DB:688a). Die tiener wat reeds op so 'n jeugdige ouderdom van haar vaderland afstand moes doen, verlang ook na 'n nasionale identiteit (DB:619a). Een ding wéét sy te midde van al die verwarring - haar identiteit is onlosmaaklik aan haar Joodse afkoms verbonde (DB:616a).

Vroeër is aangedui dat die afstand tussen die ek-verteller en die ek-figuur kleiner word in tekste waar daar ' $n$ identiteitsprobleem is. Daar kan dus aanvaar word dat 'n moontlike onderskeid tussen die ek-verteller en die ek-figuur in die dagboeke van Anne Frank baie subtiel gaan wees. Hulpmiddels wat in die beskrywing van die verhouding tussen die ek-verteller en die ek-figuur gebruik kan word, is die eienaam, die tydstruktuur, diskoerselemente en die opposisie subjek- teenoor objekposisies.

\subsubsection{Die eienaanı}

Dat die eienaam "Anne Mary Frank" bewys dat die ek-verteller en die ek-figuur dieselfde identiteit het, is ondubbelsinnig in die inskrywing van 23 Maart 1944 waarın die ek-verteller sê: "Nu over mezelf' (DB:576a).

Die intieme selfbeskouing in die inskrywing word met "je Mary Anne Frank" onderteken en dan word bygevoeg: "vergissing!" Teenoor die bladsy is 'n afdruk van die oorspronklike handskrif ingevoeg (DB:577) waarin met 'n manuskripteken aangedui word dat die volgorde van die naam "Anne Mary Frank" moet wees. Met die fout en die korreksie word die eienaam in die woorde van die outobiografiese verdrag as 'n seël op die identiteitsooreenkoms tussen die "ik" en "mezelf' dubbel en dwars beklemtoon. Dat die inskrywings gereeld onderteken word, laat die eienaam in die dagboek nog sterker as 'n sametrekkingspunt vir die ek-verteller en die ek-figuur funksioneer. Tog bewerkstellig dit soms ook 'n afstand tussen die twee instansies (DB:356b) en verleen dit 'n selfstandigheid aan die ek-figuur (DB:27lb). In 'n oomblik van besinning oor haar ongelukkige verhouding tot haar ma sê die ek-verteller byvoorbeeld (DB:472a): "Is het niet gek, Kitty, dat ik mij soms zie, met ogen als van een ander? Ik zie heel scherp hoe het met die zaken bij Anne Frank gesteld is."

\subsubsection{Tydstruktuur}

Die gereelde datering van die briewe is 'n konkretisering van die eiesoortige tydstruktuur van die egle dagboek, naamlik dat dit 'n vertelling is wat van dag tot dag gelyktydig of kwasigelyktydig met die gebeurtenisse plaasvind. Met dié 
tydstruktuur word die afstand tussen die ek-verteller en die ek-figuur in die algemeen gereduseer, maar daar is enkele retrospektiewe vertellings wat tot gevolg het dat daar tussen die "ik" wat nou aan die woord en die "ik" van die verlede onderskei kan word. 'n Voorbeeld is die kort lewensgeskiedenis wat Anne reeds vroeg in die dagboek, op 16 Junie 1942, as 'n raamwerk vir haar identiteit aanbied (DB:209a). In die gees van Coullie se wisselende subjekposisies is die kleuter wat na Nederland gekom het nie dieselfde persoon as die ek-verteller is wat so pas haar dertiende verjaarsdag gevier het nie. Die tyd as 'n skeidingselement tussen die ek-verteller en die ek-figuur word veral betekenisvol as dit ook gebeurtenisvol is, byvoorbeeld wanneer die ek-verteller op 8 November 1943 die vervreemdende gevolge van nagtelike skrikbeelde en angs beskryf. Die "eenander" en die "zelf' kom teenoor mekaar te staan (DB:433b): "Aan het Merry 5 , de vriendinnen, school, pretjes, aan dat alles denk ik als aan iets dat eenander dan ik zelf beleefd heeft."

\subsubsection{Diskoerselemente}

Oor die ek/ek-verhouding in die dagboek en die selfportret veralgemeen MusarraSchroeder (1989:50) dat dit volledig gereduseer word, veral as daar van gelyktydige vertelling sprake is. Tussen die vertelde gebeurtenisse en die vertelling word die aktiwiteite van refieksie, herinnering en verbeelding gemanifesteer waardeur die diskoers uitgebrei word, naamlik deur die persoonlike voornaamwoorde $e k-j y$, persoonlike gevoelsuitdrukkings, performatiewe en refleksiewe werkwoorde, tyd- en plekaanduidings, aanwysende voomaamwoorde en bywoorde en metateks. Die ek-jy-voomaamwoorde verskyn so oorvloedig (vergelyk byvoorbeeld die heel eerste aanhaling) dat nie verder daarop ingegaan word nie.

Anne worstel inderdaad met 'n groot verskeidenheid gevoelens en dit dra telkens tot haar innerlike verwarring by (DB:432a). Veral vrees lei daartoe dat die ekverteller haarself nie van die ek-figuur kan losmaak nie, soos byvoorbeeld blyk uit die beskrywing van haar gemoedstemming na een van die talle rusies tussen Van Pels en sy vrou (DB:428b): “Naar buiten, lucht en lachen', schreeuwt het in me; ik antwoord niet eens meer, ga op een divan liggen en slaap om de tijd, de stilte, de verschrikkelijke angst ook, te verkorten, want te doden zijn ze niet."

Hoewel haar liefde vir Peter haar innerlike konflik intensiveer (DB541a), help die tienerseun haar om haar ware self te vind, om die ek-figuur met die ek-verteller te versoen (DB:550a). Aan die einde van die dagboek is daar al hoe meer aanduidings dat die ek-verteller veral deur die krag van haar geloof en ten spyte

5 "Merry" verwys waarskynlik na 'n "merry-go-round". 
van haar innerlike verdriet met die ek-figuur versoen raak (DB:535a): "Ik had geen pratensdromen meer, ik had mezelf."

Die diskoerselemente van performatiewe en refleksiewe werkwoorde (telkens in die aanhalings deur die outeurs gekursiveer) wat in oorvloed voorkom (vergelyk ook die afdeling oor die implisiete outeur), dui op introspeksie en selfbesinning. Dikwels kom dit daarop neer dat die ek-verteller worstel om van die ek-figuur los te kom, soos byvoorbeeld in haar voortdurende botsing met die ander inwoners van Het Achterhuis (DB:337b):

's Avonds in bed, als ik over m'n vele zonden en aangedichte gebreken nadenk, kom ik zo in de war door die grote massa van deze dingen die bekeken moet worden, dat ik of ga lachen, of huilen, al naar m'n inmerlijke stemming. En slaap dan in met het gekke gevoel van anders te willen zijn, of anders te zijn dan te willen, of mischien ook anders te doen dan te willen of zijn.

Verdere diskoerselemente is die menigte bywoorde van tyd wat op die hede of kwasihede (na analogie van kwasigelyktydige) en die toekoms dui en dus die gebeurtenisse so naby aan die ek-verteller bring dat dit skaars moontlik is om temporeel van die ek-figuur afstand te neem: "Vandaag" (DB:285a), "Vannacht" (DB:375b), "Van 's ochtends" (DB:517a), "Sinds gisteren-ochtend" (DB:574a), "Gisterenmiddag" (DB:63la), "Dezelfde dag" (DB:673a) en les bes, 'n beskrywing van die oomblik van die skrywe self (DB:674a): "Eindelijk, eindelijk ben ik dan zover dat ik rustig aan m'n tafeltje voor de spleet van het raam kan zitten en je alles alles schrijven."

letwat teen die grein van die diskoersredenasie verskyn die bywoord "nu" nie soseer wanneer die ek-verteller en die ek-figuur ineengestrengel is nie, maar juis eerder om die optrede van die ek-verteller in die hede te versterk sodra die ekfiguur van die verlede haar verskyning makk. Hierdie gegewe klop wel met die beginsel dat die tydstruktuur bimne die outobiografiese genres die belangrikste onderskeid tussen die dagboek met sy gelyktydige vertelling en die outobiografie met sy retrospektiewe vertelling is. 'n Voorbeeld is die volgende inskrywing waarin ook die aanwysende bywoord van plek gevind word (DB:532a): "Als ik nu zo over m'n leventje van 1942 nadenk voelt dat alles zo onwerkelijk aan. Dit godenleventje beleefde een heel andere Anne Frank, dan die, die hier nu wijs geworden is."

Teenoor die "andere Anne Frank" staan die ek-verteller van "hier" en "nu" wat "lnadenkt" en "voelt" - almal wel diskoerselemente.

Daar is volop metateks in die dagboeke van Anne Frank, 'n diskoerselement waardeur die skrywende ek-verteller by uitstek vooropgestel word (vergelyk ook 
die voorlaaste aanhaling). Anne vertel van die terapeutiese werking van haar skrywery en wonder of sy genoeg talent het om joernalis en skrywer te word (DB:604a): "Ik hoop het, o ik hoop het zo, want in schrijven kan ik alles vastleggen, m'n gedachten, m'n idealen en m'n fantasieën."

Die ek-verteller is baie bewus van haar subjektiwiteit en worstel duidelik om daarvan los te kom (DB:447a): "Ik (oei, dat mag niet!) heb je al meer geschreven, dat we hier allemaal zoveel met stemmingen te doen hebben, en ik geloof dat dat vooral in de laatste tijd bij mij sterk toeneemt."

\subsubsection{Subjekposisies teenoor objekposisies}

Subjek- en objekposisies is baie bruikbare leidrade om subtiel tussen die ekverteller en die ek-figuur te onderskei. Die vreugde van die liefde, haar vrolike geaardheid, entoesiasme en positiewe ingesteldheid vat Anne goed saam in 'n gelukkige oomblik in haar lewe (DB:649a): "Ik ben niet meer alleen, hij houdt van me, ik houdt van hem, ik heb m'n boeken, m'n schrijfboek en m'n dagboek, ik ben niet zo erg lelijk, niet zo heel erg dom, heb een vrolijke natuur en wil een goed karakter krijgen!"

In sulke oomblikke word die ek-figuur in die ek-verteller opgeneem, soos wat die oorheersing van die "ik" in die subjekposisies getuig. Ander kere is dit duidelik dat die "ik" (onderstreep in DB) in die subjekposisie haar van die "me" in die objekposisie sou wou distansieer (DB:688a): "Hoe komt het dan, vraag ik me zo vaak af, dat iedereen me nog steeds zo ontzettend eigenwijs en onbescheiden vindt? Ben ik zo eigenwijs? Ben $\underline{\mathrm{ik}}$ het werkelijk of zijn het misschien niet ook de anderen?"

Dat "Anne" in die heel laaste inskrywing, gedateer Dinsdag, 1 Augustus 1944 (DB:711a-713a), soms die subjekposisie, soms die objekposisie inneem, gee 'n aanduiding hoe verhouding tussen die ek-verteller en die ek-figuur op 'n spanningslyn tussen identifisering en afstandneming beweeg. 'n Kort uittreksel word aangebied: “... de mooie zijde van Anne kent niemand ... Je kunt je niet voorstellen hoe vaak ik niet al geprobeerd heb, deze Anne, die maar de helft van alles wat Anne heet is ..."

Die opposisie subjek- teenoor objekposisies word konkreet gesubstansieer in wat portrettegnieke genoem kan word. Die beskrywings deur die ek-verteller van die fisiese Anne kom in baie opsigte ooreen met Béatrice Didier se opvatting van die literêre selfportret wat deur Musarra-Schroeder (1989:47) só opgesom word: die $e k$ of die self word van buite beskryf soos deur 'n skilder voor 'n spieël op soek na homself. ' $n$ Konkrete voorbeeld is die volgende (DB:468a): 
Ik heb in de spiegel m'n gezicht gezien en dat ziet er zo anders uit, dan anders. M'n ogen zien zo helder en zo diep, m'n wangen zijn, wat in weken niet gebeurd is, rose gekleurd, m'n mond is veel weker, ik zie er uit of ik gelukkig ben en toch is er zo iets droevigs in m'n uitdrukking, m'n glimlach glijdt meteen van m'n lippen af.

In Coullie se idioom word twee onderskeie gesigte in die teks opgeroep, een vóór en een in die spieël, maar aan die ander kant is die beelde op die moment van waarneming visueel identies aan mekaar. Uit die vertellerskommentaar blyk egter dat die onmiddellike beeld in die spieël nie die enigste visuele weergawe van die ek-verteller nie is - dit verander soos wat die persoon voor die spieël verander. Identiteit is nie vas nie, maar word binne wisselende subjekposisies gekonstitueer.

Dat daar tussen die ek-verteller en die ek-figuur onderskei kan word, word nog sterker bevestig deur die foto's as beeld van die verhouding tussen die ekverteller en die ek-figuur. Die ondersoekende ek-verteller met haar vertellersteks en die fotobeelde van die ek-figuur kan albei met die eienaam "Anne Frank" aangedui word. Die gesigsuitdrukkings of die houdings op die foto's verskil egter, terwyl die ek-figuur op die foto's wat op bepaalde momente in die geskiedenis gestol is, nie saam met die ek-verteller verander het soos in die geval van die spieëlbeeld nie. Verder vorm die vertellersteks 'n agternaperspektief (DB:300a): "Dit is een foto, zoals ik me zou wensen, altijd zo te zijn. Dan had ik nog wel een kans om naar Holywood te komen. Maar tegenwoordig zie ek er jammer genoeg meestal anders uit." (Kyk foto en kommentaar op p. 66.)

lets van die vele fasette of wisselende subjekposisies van die ek-figuur in een van die reekse klein foto'tjies word deur die vertellerkommentaar vasgevang (DB:299a):

\section{Zo kijk ik in een kinderwagen}

en zo in een spiegel

Hier heb ik zeker naar de harlekijn gekeken. Anne.

Dit is ook snoezig hé. Anne.

Samevattend kan die verhouding tussen die ek-verteller en die ek-figuur in die dagboeke van Anne Frank as 'n spanning tussen 'n algehele eenwording en 'n subtiel waameembare distansiëring beskryf word. Hoewel 'n ek-figuur dus onderskei kan word, is die band tussen die twee ekke baie-baie heg. In die algemeen hou dit in dat dit waarskynlik heelwat moeiliker is on tussen die ekverteller en die ek-figuur in die dagboek as in die outobiografie te onderskei - 'n gegewe wat klop met Musarra-Schroeder se bewering dat die ek/ek-verhouding in die dagboek gereduseer word. Coullie se pleitrede vir 'n duidelike onderskeid tussen ek-verteller, die ek-figuur, die implisiete outeur en die werklike outeur in 
die outobiografie sal dus in die geval van die dagboek ten opsigte van die verhouding tussen die ek-verteller en die ek-figuur getemper moet word. Vir die dagboeke van Anne Frank beteken die eenwording tussen die ek-verteller en die ek-figuur - wat dikwels daarop neerkom dat die ek-figuur in die ek-verteller opgeneem word - dat daar uit één mond vertel word, maar dat dit dan 'n versterkte vertelling is.

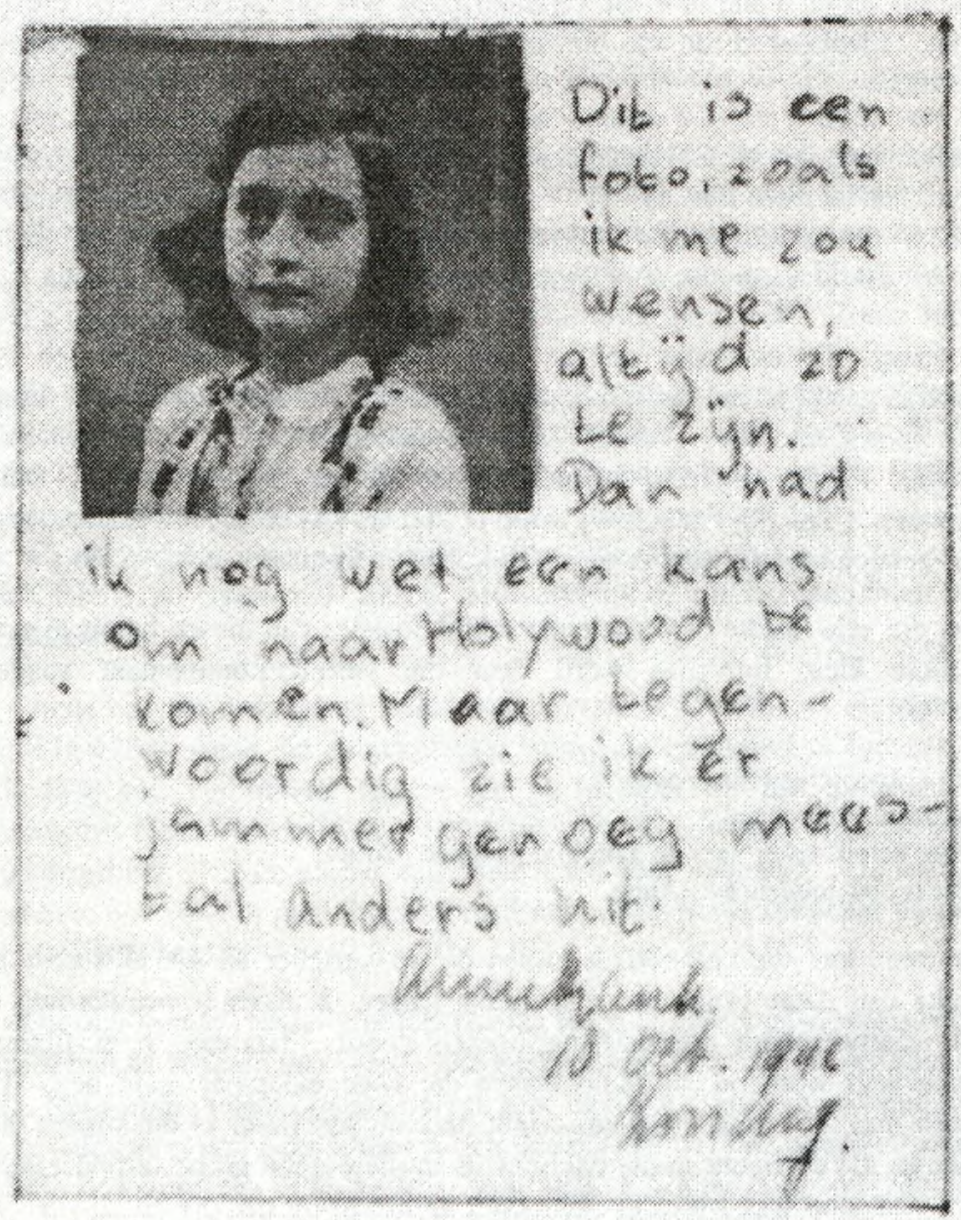

Figuur 1: Die ek-figuur en die ek-verteller (vertellerskommentaar) 


\subsubsection{Die implisiete outeur en die ek-verteller/ek-figuur}

Die verhouding tussen die implisiete outeur en die ek-verteller en ek-figuur kan prakties aan die hand van menings oor spesifieke sake en die ingesteldheid teenoor die werklikheid ondersoek word. Die ondersoek vind plaas teen die agtergrond van die gevolgtrekking dat daar 'n baie noue band tussen die ekverteller en die ek-figuur bestaan. Om dié rede word die ek-verteller/ek-figuur as 'n eenheid beskou, behalwe wanneer daar duidelik verskillende verhoudings tussen die implisiete outeur en onderskeidelik die ek-verteller en ek-figuur aangedui kan word.

\subsubsection{Menings oor spesifieke sake}

Spesifieke sake waaroor daar 'n mening uitgespreek word, is byvoorbeeld oorlog (DB:642a), die liefde (DB:523a), die vrou (DB:523a), die soeke na geluk (DB:537a en 697a), die helende werking van die natuur (DB:69la) en godsdiens (DB:698a). Enkele voorbeelde word bespreek om die tipiese verhouding tussen die implisiete outeur en die ek-verteller en ek-figuur te illustreer. Dat rusie en konflik eie aan die mens is, spreek oral uit die dagboeke, van die begin tot die einde (DB:250b, DB:372b, DB:587a en DB:663a). Hierdie totale beeld van die strydlustigheid van die mens word eksplisiet ook die oortuiging van die ekverteller as die "ik" in 'n subjekposisie met die performatiewe "geloof' verbind word (DB:642a) 6: "Ik geloof nooit dat oorlog alleen van de grote mannen, van de regeerders en kapitalisten komt, o nee, de kleine man doet het net zo goed graag ..."

In die volgende aanhaling word dié oortuiging deur die performatiewe "vind" ook op die klein kring van die Het Achterhuis toegepas (DB:270a): "Ik vind het heel gek dat volwassen mensen zo gauw, zo veel en over alle mogelijke kleinigheden ruzie maken; tot nu dacht ik altijd dat kibbelen een kindergewoonte was, die later uit zou slijten."

Vroulikheid - merkwaardig feministies gekleur - figureer sterk in die dagboeke: in die ek-verteller/ek-figuur se belangstelling in die ontwikkeling van haar liggaam (DB:584a), die vreugde oor 'n nuwe paar skoene (DB:4l lb) of die ontroering oor die skoonheid van Venus (DB:459ac-460ac). Dié vroulikheid word nie deur swakheid gekenmerk nie, maar deur 'n noodsaaklikheid om op eie bene te staan (DB:697a) en bereik 'n hoogtepunt in 'n pleitrede vir meer waardering en regte vir die vrou (DB:692a). Met die beroep op die boek Strijders voor het leven van Paul de Kruif word die oortuiging van die implisiete

6 Kursivering in dic aanhalings deur dic outcurs van hicrdic artikel. 
outeur uitgebou. Die ek-verteller vereenselwig haar met De Kruif se opvattings (DB:692a):

Ik geloof dat als het inzicht, dat het de plicht v.d. vrouw is, dat zij kinderen krijgt, in de loop van de volgende eeuw wel zal veranderen, en plaats zal maken voor waardering en bewondering voor haar die zonder mopperen en grote woorden, de lasten op haar schouders neemt!

$\mathrm{Na}$ 'n sessie van die verwerking van ertjies "weet" die ek-verteller dat sy as vrou "nooit, nooit alleen maar huisvrouw wil zijn!" (DB:702). Haar droom om van 'n bekrompe lewe weg te kom en in Parys en Londen te studeer, bou voort op die oortuiging van die implisiete outeur (DB:650a-651a).

Uit die aard van die saak is die Franks Jode, en Anne is baie uitgesproke daaroor dat hulle altyd Jode sal bly (DB:616a), maar sy is nie 'n ortodokse Jood nie. Die erkenning van ander godsdienste word gekonkretiseer in die vriendskap van die groepie Jode met Christene, soos duidelik blyk uit die versorging van die Jode deur Christene (DB:674a), en daarin dat Anne se vader 'n kinderbybel vir haar soek sodat sy ook oor Jesus Christus kan lees (DB:439bc). Die waarde wat aan godsdiens geheg word, word in die algemene besinning ("Mensen ... het is niet elke gegeven ... te geloven") oor godsdienstigheid saamgevat (DB:698a-698a):

Mensen die een godsdienst hebben mogen blij zijn want het is niet elk gegeven aan bovenaardse dingen te geloven. Het is niet eens nodig bang te zijn voor straffen na de dood; het vagevuur, de hel en de hemel zijn dingen die velen niet aan kunnen nemen, maar toch houdt de een of andere godsdienst, welke het is doet niets ter zake, de mens op het goede pad.

Hierdie opvatting vind weerklank in die ek-verteller/ek-figuur se groot teleurstelling in Peter se houding teenoor godsdiens (DB:689a): "Vooral z'n godsdienstafkeer ... bevallen mij niet."

Afgesien daarvan dat die voorbeelde van oorlog, die vrou en godsdiens aantoon dat die implisiete outeur kongruent aan die opvattings van die ek-verteller/ekfiguur is, is dit ' $n$ wesentlike kenmerk van die dagboeke dat die implisiete outeur nie net op 'n volgehoue manier en so frekwent deur woorde van mening geëksplisiteer word nie, maar dat dit ook deur die verbinding van performatiewe werkwoorde aan die "ik" in die subjekposisie keer op keer eksplisiet één met die ek-verteller word. Dit hou in dat moontlike spanning tussen die instansies grootliks opgelos word. Weer eens word die vertelfunksie versterk.

\subsubsection{Ingesteldheid teenoor die werklikheid}

Die verhouding tussen die implisiete outeur en die ek-verteller/ek-figuur kan verder op grond van die ingesteldheid teenoor die werklikheid getoets word. Die 
algemene gesindheid is primêr 'n positiewe gesindheid (DB:697a) wat ten spyte van 'n groot komponent van neerslagtigheid, angs en depressie (DB:675a) gekemmerk word deur lewensblyheid (DB:710a), humor (DB:642a), geloof in God (DB:534a en 599a) en hoop op die toekoms (DB:650a en 671a). Verder spreek 'n ongelooflike volwassenheid uit die dagboeke (DB:475a en DB:560a), maar daar is ook iets van 'n jeugdige romantiek te midde van al die oorlogsellende te bespeur (DB:642a).

'n Tipiese voorbeeld van die positiewe houding is dat die ek-verteller na bykans twee jaar van ontbering, swak kos, nie te wafferse klere nie, 'n benouende lewensruimte, aanhoudende konflik met die mede-inwoners, tye van innerlike onsekerheid en stryd, angs en vrees vir oorlogsgeweld en Jodevervolging, op 3 Mei 1944 nog kan besin (DB:643a):

Ik heb veel meegekregen, een gelukkige natuur, veel vrolijkheid en sterkte. Elke dag voel ik hoe m'n innerlijk groeit, hoe de bevrijding nadert, hoe mooi de natuur is, hoe goed de mensen in m'n omgeving, hoe interessant en amusant dit avontuur! Waarom zou ik dan wanhopig zijn?

In die reddende, dikwels selfontluisterende humor word die ek-figuur in 'n mate van die ek-verteller losgemaak. As Anne oor Miep se vertelling van haar niggie se verlowingsparty skryf, kyk die ek-verteller as't ware op 'n afstand na die groepie toehoorders waarvan die ek-figuur een is en op daardie oomblik waarskynlik niks amusants in die situasie sien nie. Die implisiete outeur en die ek-verteller skuif dus ineen, maar ooreenkomstig die verhouding tussen die ekverteller en ek-figuur vind 'n distansiëring tussen die implisiete outeur en die ekfiguur plaas (DB:652a):

Ik kan je zeggen, dat we de woorden uit Mieps mond trokken, dat we om haar heen stonden of we nog nooit in ons leven van lekker eten of chieke mensen hadden gehoord! En dat zijn de kleindochters van de befaamde milionair, het loopt toch wel gek in de wereld!

Soos die implisiete outeur vereenselwig die ek-verteller haar met die traan én die lag soos wat dit deur die volgende besinning van die "ik" in die subjekposisie bevestig word (DB:642a): "lk ben vaak neerslachtig geweest, maar nooit wanhopig, ik beschouw dit schuilen, als een gevaarlijk avontuur, dat romantisch en interessant is. Ik beschouw elke ontbering als een amusement in mijn dagboek."

Soms kom daar 'n verwydering tussen die implisiete outeur enersyds en die ekverteller én ek-figuur andersyds deurdat die positiewe lewenshouding deur 'n siniese ek-verteller teëgespreek word (DB:671a), of deurdat die ek-verteller erken dat die omstandighede glad nie so romanties is nie (DB:244a). Na aanleiding van Miep se vraag of die inwoners van Het Achterhuis dink dat hulle 
ook met die anti-semitisme besmet is, sak 'n vertwyfeling op die anders positiewe ek-verteller/ek-figuur toe (DB:676a): "Ik vraag me steeds weer af of het niet beter voor ons allemaal was geweest als we niet waren gaan schuilen, als we nu dood waren en deze ellende niet mee maakten en vooral al de anderen spaarden."

Dat die ek-verteller aan die implisiete outeur ondergeskik is, blyk daaruit dat die implisiete outeur die uitsprake van die ek-verteller/figuur relativeer. In die volgende uitspraak is die korrektief 'n agternaperspektief wat daarop dui dat die rol van die implisiete outeur met 'n tydsafstand opvallender word of omgekeerd dat die implisiete outeur net soos die ek-figuur in gelyktydige vertelling steeds nader aan die ek-verteller kom (DB:396v): "Wil de lezer even onder de ogen zien, dat toen dit verhaal geschreven is, de schrijfster nog niet van haar woede bekoeld was!"

Een aspek waarop nog gewys word, is dat die implisiete outeur 'n samestelling van veranderende opvattings van die ek-verteller is. Tussen die inskrywings van Junie 1942 is die volgende aantekening later op 28 September 1942 ingevoeg (DB:212a): "Als ik vaak bij geschreven stukjes, wat bij heb geschreven, of bij zal schrijven, is dit alleen voor de verbetering of om de dingen van mijn nieuw standpunt te bekijken."

Hoewel daar soms 'n verwydering tussen die implisiete outeur en die ek-verteller en/of die ek-figuur in hulle ingesteldheid teenoor die werklikheid voorkom, vind daar meesal ook hier 'n absolute eenwording tussen dié vertelinstansies plaas, veral deur die performatiewe werkwoorde keer op keer aan die "ik" in die subjekposisie te verbind. Die merkwaardige bly steeds dat die implisiete outeur op so 'n volgehoue manier en so frekwent geëksplisiteer word, sodanig dat daar ook 'n eksplisiete outeur in die dagboeke van Anne Frank onderskei kan word. Hierdie eksplisiete outeur is die konkrete tekstuele neerslag van die teoretiserende "Anne" van die "Anne-teorieë". Die kommunikatiewe krag van die eksplisiete outeur word verder in die aard van die performatiewe woorde hulle is taaldade - gesubstansieer, en na die ek-verteller oorgedra.

\subsubsection{Die werklike outeur en die implisiete verteller/ek-verteller/ek-figuur}

Die werklike outeur is die werklike mens Anne Frank. Hoewel die poststrukturaliste beweer dat die werklike mens nooit in 'n teks agterhaal kan word nie, ook nie in 'n wetenskaplike of 'n historiese dokument nie, kan die goed gedokumenteerde navorsing van Paape (1986a, 1986b, 1986c en 1986d) gebruik word om 'n raamwerk van die werklike Anne te konstrueer. Soos wat die tekstuele konstruksie vorder, sal die verhouding tussen die werklike Anne (histories gekonstrueer) en die ek-verteller/ek-figuur/implisiete outeur/eksplisiete outeur ondersoek word. Vir praktiese doeleindes word na laasgenoemde as "Anne" verwys. 


\subsubsection{Persoonlike besonderhede oor Anne Frank}

Volgens Paape (1986a:1-8) is "Anne" die noemnaam van Anneliese Marie Frank wat op 12 Junie 1929 in Duitsland gebore is. Sy is die jongste dogter van Otto en Edith Frank. Haar ouer suster, Margot Betti, is op 16 Februarie 1926 gebore. Anne se vader, Otto Heinricl Frank, wat op 16 Augustus 1933 in die bevolkingsregister van Amsterdam opgeneem is, is op $12 \mathrm{Mei} 1889$ gebore en is die tweede seun van Michael Frank en Alice Betty Stern. Michael Frank was 'n bankier. In die lente van 1925 trou Otto Frank op ses-en-dertigjarige ouderdom met die vyfen-twintigjarige Edith Holländer, die dogter van 'n "fabrikantenechtpaar" uit Aken. Die besluit van Otto Frank om na Nederland te emigreer, word aan die druk van die Nazi's toegeskryf. In die somer van 1933 neem lyy sy gesin na sy skoonmoeder in Aken waar hulle voorlopig agterbly toe hy Amsterdam toe gaan. Terwyl Otto Frank besig is om sy sakebelange te vestig, vind hy in die herfs van 1933 ook 'n geskikte woning vir sy gesin op die tweede vloer van Merwedeplein 37. Op 16 Augustus word hy en sy vrou in die Amsterdamse bevolkingsregister opgeneem, maar Edith bly nog ongeveer vier maande saam met haar kinders in Aken. Die verhuising na Merwedeplein word op 5 Desember geregistreer. Twee dae later word Margot en Anne ook by die nuwe adres ingeskryf. Hierdie historiese gegewens van Paape stem grootliks ooreen met die lewensverhaal wat Anne aan die begin van die dagboek op 16 Junie 1942 opskryf (DB:202a):

idioot Mijn geschiedenis. zoiets vergeet men niet

Ik ben geboren op 12 Juni 1929 in Frankfort a/M. Tot mijn 4de jaar woonde ik in Frankfort, toen is mijn vader Otto, Heinrich Frank naar Holland om een betrekking te zoeken dat was in Juni. Hij vond wat, en zijn vrouw Edith Frank-Holländer ging in September ook naar Holland. Margot en ik gingen naar Aken, waar onze grootmoeder Rosa Holländer-Stern woondde [sic!], Margot is in December naar Holland, en ik in Februari waar ik als verjaardagcadeaux bij Margot op tafel werd gezet. ${ }^{7}$

Sy gaan voort om van haar kleuterskooljare en van haar skoolloopbaan en onderwysers te vertel. Die band tussen die wêreld van die werklike Anne en die Anne van die dagboeke word verder versterk in haar stukkie familiegeskiedenis wat sy op $8 \mathrm{Mei} 1944$ in die dagboek opneem (DB:650a) en as sy op $13 \mathrm{Mei}$ 1944 beskryf hoe hulle haar vader se verjaarsdag en die herdenking van haar ouers se troudag die vorige dag gevier het (DB:662a).

Skynbaar was die Franks volgens Paape (1986a:18) baie gelukkig in hulle huis langs die Merwedeplein - vir Anne was dit "een goed thuis" (DB:20lb). Toe

7 Volgens Paape (1986a 8) hocf dit nic in stryd te wees met dic familicherinnering dat Edith en Margot definiticf in Desember na Amsterdain gekom het en dat Anne cers in Maart (Februarie?) 1934 gehaal is nic. Dic registrasic kon in Anne se afiscsighcid geskied het 
ook ouma Holländer in 1939 van Aken na Nederland uitwyk, trek sy by die gesin in waar sy tot haar dood in Januarie 1942 bly. Anne vertel van die ouma wat by lulle kom bly het en dat sy in die somer van 1941 baie siek geword en in die winter van 1941-1942 gesterf het (DB:202a). By 'n foto van Anne en Margot met ouma Holländer in die agtergrond skryf sy dat sy wens dat haar ouma nog die huislike vrede kon bewaar (DB:210a).

Paape (1986a:19) merk op dat die verlede in Duitsland al verder teruggewyk het. Die Franks word tuis in Nederland - veral die kinders vernederlands sterk (DB:671). Die Nazi-bedreiging het hulle egter weer ingehaal. Die stortvloed van wette teen die Jode in 1941 en 1942 (DB:202a) word deur Anne bekla. Uit vorms gedateer 20 Januarie 1942 blyk dit volgens Paape (1986a:19-20) dat Otto Frank 'n laaste poging aanwend om weer te emigreer om saam met sy vrou en kinders aan die greep van die Nazi's te ontsnap, maar van die begin van Mei 1942 moet die gesin Frank ook die geel Joodse ster dra. Anne spreek haar misnoeë uit dat sy orals heen moet loop, omdat die Jode nie van openbare vervoer gebruik mag maak nie (DB:218a).

Ten slotte word opgemerk dat die Franks vir die buitewêreld na die begin van Julie 1942 nie meer in Nederland was nie - hulle het gevlug. Die verhaal dat 'n kaptein uit die leër die Franks waarskynlik gehelp het on na België te vlug (DB:240b), het volgens Paape (1986c:33) met oortuiging die rondte gedoen. Dr. Pfeffer se verbasing toe Miep hom bring om by die skuilers aan te sluit, is 'n bewys daarvan (DB:328).

\subsubsection{Sakeloopbaan van Otto Frank}

Die sakeloopbaan van Otto Frank word in die fynste besonderhede deur Paape (1986a:3 e.v.) beskryf. Die doel van die gedetailleerde en bibliografies verantwoorde dokument is om bo alle twyfel te bewys dat Otto Frank dwarsdeur die oorlog op 'n nieamptelike wyse vanuit Het Achterhuis by die sakeondernemings te Prinsengracht 263 betrokke was, en dat die ongelooflike werklikheid van die dagboeke deur die historiese konstruksie gerugsteun word. Enkele raakpunte in die dagboeke is dat Anne vertel dat hulle vanweë luulle Joodse identiteit in 1933 na Nederland emigreer "waar m'n vader aangesteld werd als directeur van de Nederlandse Opekta Mij. voor jambereiding" (DB:202b). Paape (1986a:8-11) beskryf hoe Anne se vader en sy sakevennote die ondernemings deur 'n reeks slim onderhandelings so geariseer het dat hy amptelik geen aandeel in hulle gehad het nie. Op 5 Julie 1942 (DB:224b) merk Anne op dat haar vader nou dikwels by die huis is, want Kleiman het Opekta en Kugler Gies en Co. oorgeneem. Laasgenoemde, sê sy, is 'n maatskappy wat met surrogaatkruie handel dryf en is pas in 1941 gestig. Paape (1986a:17) is van mening dat die besoek van die direkteure van Pomosin in Frankfurt waaroor Anne in haar dagboek op 1 April 
1943 (DB:370b) skryf, waarskynlik ook op die arisering betrekking het. Tekstuele aanduidings van die funksionering van die twee sakeondernemings is Anne se vertelling oor die ontpitting van kersies met die oog op inlê (DB:237b), die verpakking van braaisouspoeier (DB:348b) en die verwerking van aarbeie (DB:699a-701a) en ertjies (DB:701a). As die kat onsindelik is, is dit nie nét die geur van peper en tiemie wat in Het Achterhuis hang nie (DB:678a)!

\subsubsection{Spesiale vriende van die Franks}

'n Aantal spesiale vriende van die Franks wat histories deur Paape (1986a) gekonstrueer word, knoop die wêreld van die werklike Anne aan die wêreld van die Anne in die dagboeke. Hulle is eerstens nie-Jode wat die Franks later sou help om in Het Achterhuis te skuil en tweedens Jodegenote wat saam met Annehulle sou skuil. Die meeste van hulle is ook kollegas van Otto Frank.

Johannes Kleiman was die langste met die Franks bevriend en het 'n belangrike rol in die sakeonderneming gespeel (Paape, 1986a:3,10-21). In die teks figureer Kleiman as die persoon wat gereeld vir Anne boeke aandra (DB:236b en DB:258a) en wat ten spyte van 'n maagseer altyd vol lewensblyheid was (DB:421b, DB:427b, DB:574a en DB:64la). Een van die vriende van voor die skuilperiode en 'n steunpilaar in die sakeonderneming, is Miep Santrouschitz wat op tienjarige ouderdom as een van die baie ondervoede Oostenrykse kinders aan Nederlandse pleegouers toevertrou is en in die somer van 1942 met Jan Gies getroud is (Paape, 1986a:9). Die tekstueel gekonstrueerde Miep is iemand wat hart en siel met die skuilers en die Jode in die algemeen meeleef (DB:306a en DB:284a). Victor Gustav Kugler was ook 'n Oostenryker wat in 1920 Utrecht toe gekom het en in 1938 as Nederlander genaturaliseer is - hy is Otto Frank se regterhand in die sakeonderneming (Paape, 1986a:8). Vir Anne is Kugler "de directeur" voor in die kantoor wat baie swaar gedra het aan sy verantwoordelikheid vir die Jode (DB:423a). Naby aan die einde van hulle verblyf in Het Achterhuis skryf Anne op 26 Mei 1944 soos volg oor die taak en die verantwoordelikheid van die helpers (DB:674a):

Miep en Kugler ondervinden het meest de last van ons en al de schuilers, Miep in haar werk, Kugler die de kolossale verantwoording van ons 8 soms te machtig wordt en die bijna niet meer spreken kan van ingehouden zenuwen en opwinding. Kleiman en Bep zorgen ook goed voor ons, maar eenmaal is voor hun ook het Achterhuis vergeten, al is het maar voor een paar uurtjes, een dag, twee dagen misschien.

Teenoor die karige historiese konstruksie van die die mede-inwoners, kan ryke konstruksies uit dic tekstuele gegewens van hulle opgebou word. Hermann van Pels wat in die somer van 1937 saam met sy vrou en tienjarige seun vir die Naziregime uit Osnabrück na Nederland gevlug het, het vanweë sy kemnis van kruie 
en speserye by Otto Frank se sakeonderneming betrokke geraak (Paape, 1986a:10-11, 18). Die persoonlikhede van die egpaar Van Pels is deel van die moeilike lewensomstandighede van Anne in die teks (DB:653a, DB:406b-407b en DB:396b). Aanvanklik beïndruk Peter Anne geensins nie (DB:238a en DB:249b), maar gaandeweg ontdek sy dat hulle geesgenote is (DB:563a-565a) en dat sy hom liefhet (DB:467a). Ook vir dr. Fritz Pfeffer, die 54-jarige man met wie Anne 'n kamer moes deel en wat haar so baie ellende besorg het (DB:655a), konstrueer Paape (1986a:18-19) 'n historiese raamwerk - hy was 'n tandarts en vriend van die Franks.

\subsubsection{Die arrestasie en daarna}

Die lotgevalle van die personeel van Prinsengracht 263 en die skuilers in Het Achterhuis tydens en na die arrestasie word deur Paape (1986b en 1986c) beskryf. Teenoor die baie goed gedokumenteerde historiese konstruksie van byvoorbeeld Otto Frank se sakeloopbaan, is die ingrypende gebeurtenisse van 4 Augustus 1944 in vaagheid gehul - ten spyte van eksakte juridiese en historiese ondersoeke. Van die fragmentariese besonderhede wat oor die Jode en hulle helpers bekend is (Paape, 1986d:57-63), word enkeles hier genoem. Die agt Jode het die hele Augustus in Westerbork gebly, en volgens 'n getuie was Anne en Peter voortdurend bymekaar en het Anne stralend gelukkig gelyk. Die aangrypende is dat die trein waarop die gesin van Otto Frank gedeporteer is, die laaste een was wat vanaf Westerbork na Auschwitz vertrek het. Net Otto Frank het die oorlog oorleef. Die ander is die een na die ander oorlede, óf deur vergassing óf vanweë ontberinge. Margot en Anne het die langste bly leef en is waarskynlik einde Februarie, begin Maart aan tifus oorlede. ${ }^{8}$

\subsubsection{Egtheid van die dagboek}

'n Verdere aspek wat die historiese konstruksie van Anne geloofwaardig maak, is die getuienis van Miep en Bep op 5 Junie 1974 dat die dagboeke eg is (Paape, 1986c:47). Verder kom Hardy (1986:186) op grond van uitgebreide navorsing oor die handskrif van die dagboeke tot die gevolgtrekking dat dit ongetwyfeld dié van Anne is.

\subsubsection{Samevatting}

Die historiese konstruksie van Anne Frank deur Paape (1986a, 1986b, 1986c en 1986d) en die tekstuele dagboekkonstruksie van Anne Frank (die ek-verteller/ekfiguur/implisiete outeur/eksplisiete outeur) stem in so 'n mate met mekaar ooreen

8 Oor dic implikasics van dic stukkic geskicdenis na 4 Augustus vir dic kommunikasicsituasic word in Reinecke en Van der Elst (1995:92-105) ingegaan. 
dat beweer kan word dat hulle albei na dieselfde persoon in die werklikheid verwys, maar terselfertyd is dit ook duidelik dat die twee konstruksies nie identies aan mekaar is nie. Om die waarheid te sê, hulle kan baie duidelik van mekaar onderskei word. Teenoor die droë historiese geraamte is daar in die dagboekteks 'n mens met 'n duidelike fisiese voorkoms en 'n afgetekende persoonlikheid. 9 Die spanningslyn tussen identifisering en afstandneming onder die vertelinstansies kan dus na die werklike outeur deurgetrek word, met 'n sterk neiging na identifisering.

Terselfdertyd móét ook tot die gevolgtrekking gekom word dat nóg die historiese nóg die tekstuele konstruksie van Anne Frank identies aan die werklike Anne Frank of die werklike outeur kan wees. Soos wat die poststrukturaliste beweer, is dit onmoontlik om die werklike mens volkome te agterhaal - selfs ook in wetenskaplike en historiese dokumente soos Paape se oorspronklike verslae; trouens, oor sekere gebeurtenisse, soos die arrestasie, bestaan daar heelwat onsekerheid.

\section{Gevolgtrekkings}

In die taal van Coullie kan in die dagboeke van Amne Frank nie net tussen vier instansies in die vertelsituasie onderskei word nie, maar tussen vyf. In die vyfvoudig versterkte vertelsituasie word die boodskap persuasief oorgedra, en funksioneer die teks volgens die insig van Gititi duidelik as 'n getuienis van die werklikheid.

Aan die ander kant is daar ook 'n identiteitsooreenkoms tussen die vyf instansies in die vertelsituasie, nie in die sin dat hulle absoluut identies aan mekaar is nie, maar dat hulle na dieselfde persoon in die werklikheid verwys. Dié vertelsituasie is dus naas ander literêre eienskappe nóg 'n tekstuele strategie om die werklikheid getrou binne-in die dagboeke te plaas. Bruss se eerste reël vir die outobiografiese skryfwyse wat ook die kern van Lejeune se outobiografiese verdrag vorm, kan nou na 'n dagboekverdrag uitgebrei word: die eienaam wat op die titelpagina verskyn, is 'n seël op 'n verdrag tussen die werklike outeur, die eksplisiete outeur, die implisiete outeur, die ek-verteller en die ek-figuur met die leser dat daar 'n identiteitsooreenkoms tussen die verskillende instansies in die vertelsituasie is. Hierbenewens is die volgehoue eksplisitering van die implisiete outeur 'n konkrete vergestalting van Bruss se tweede en derde reël vir die outobiografiese skryfwyse, naamlik die waarheids- en opregtheidsintensie. Daar

9 In dic ondersock van dic tochoorderinstansies as decl van dic totale kommunikasicsituasic word aangedui hoc dic leser dic tekstucle en historiesc Anne Frank kan laat leef (Reinecke \& Van der Elst, 1995:92-105). 
wil openlik en sonder om doekies om te draai gesê word dat bepaalde waardes meegedeel word en wáár is. Hiermee word 'n herwaardering van eksplisitering teenoor implisitering - in die literatuur gevra. Die kwaliteit van die waarlieid sal uiteindelik ook in die lig van die persoonlikheid van die ek-verteller beoordeel word, ' $n$ aspek wat onder die rol van fokalisasie tuishoort.

Die werklikheidsgetrouheid en die drang na waarheid wat in die vertelsituasie gesubstansieer word, word ondersteun deur die tradisionele sine qua non van die dagboek, naamlik die gelyktydige of kwasigelyktydige tydstruktuur van die dagboek, terwyl die aanhoudende onderlinge toenadering tussen die verskillende vertelinstansies metafories van 'n eeu-oue kenmerk van die dagboek word, naamlik die soeke na identiteit.

\section{Bibliografie}

Bal, M. 1985. De theorie van vertellen en verhalen: inleiding in de narratologie. $3 \mathrm{e} \mathrm{dr}$. Muiderberg : Coutinho

Booth, W.C. 1982. The rhetoric of fictiom. 2nd ed. Chicago : University of Chicago Press.

Briosi, S. 1989. Over het literaire karakter van de autobiografie In: Jongeneel, E. red. Over de aurobiografie. Utrecht: Hes Uitgevers, p. 57-63.

Broeksma-Van Capella, E. 1991. Die biografie van een kameleon: gesprek met Jan Fontijn. Maatstaf, 39(1):70-80, Jan.

Brolsma, S. 1982. Dagboeken: een verkenning. Maatstaf, 30(11-12):1-26

Coullie, J.L. 1991. "Not quite fiction": the challenges of Poststructuralism to the reading of contemporary South African autobiography. Currem writing, 3(1):1-23.

Fontijn, J. 1992. De Nederlandse schrijversbiografie. Utrecht: Hes Uitgevers.

Gititi, G 1991. Self and society in testimonial literature Caesarina Kona Makhoere's No child's play: In prison under apartheid. Current writing, 3(1):42-49.

Hardy, Ir. H.J.J. 1986. Samenvatting van de resultaten van het handschriftvergelijkend en document-technisch onderzoek van wat bekend staat als het dagboek van Anne Frank. In: Rijksinstituut voor Oorlogdocumentatie. De dagboeken van Anne Frank 's-Gravenhage : Staatsuitgeverij Bert Bakker. p. 121-186.

Jacobs, J.U. (ed.) 1991a. Current writing, 3(1). Durban : Department of English, University of Natal.

Jacobs, J.U. 1991b. Preface: Autobiography in South Africa. Current writing, 3(1):i-iv.

Jongeneel, E. red 1989. Over de autobiografie. Utrecht: Hes Uitgevers.

Musarra-Schroeder, U. 1983. Narcissus en zijn spiegelbeeld. Assen : Van Gorcum. (Puntkomma-reeks; 15.)

Musarra-Schroeder, U. 1989. Vormen van "autobiografisch schrijven". In: Jongeneel, E. (red.) Over de autobiografie. Utrecht: Hes Uitgevers. p. 41-56.

Paape, H. 1986a. “... komende van Frankfort a/d Main". In: Rijksinstituut voor Oorlogsdocumentatie. De dagboeken van Ame Frank ... 's-Gravenhage : Staatsuitgeverij Bert Bakker. p. 1-23.

Paape, H. 1986b. De arrestasie. In: Rijksinstituut voor Oorlogsdocumentatie. De dagboeken van Amme Frank ... 's-Gravenhage: Staatsuitgeverij Bert Bakker. p. 25-32.

Paape, H. 1986c. Het verraad. In: Rijksinstituut voor Oorlogsdocumentatie. De dagboeken van Amme Frank ... 's-Gravenhage : Staatsuitgeverij Bert Bakker, p. 33-56. 
Paape, H. 1986d. Gevangenschap en deportatie. In: Rijksinstituut voor Oorlogsdocumentatie. De daghoeken van Amme Frank ... 's-Gravenhage : Staatsuitgeverij Bert Bakker. p. 57-67

Reinecke, C. \& Van der Elst, J. 1995. 'n Ondersoek na die dagboek met besondere verwysing na die dagboeke van Ame Frank. Verslag van navorsing met 'n ad hoctoekenning van die Sentrum vir Wetenskapsontwikkeling. [Potchefstroom]. (Ongepubliseerde navorsingsverslag.)

Rijksinstituut voor Oorlogsdocumentatie. 1986. De dagboeken van Anme Frank. Ingeleid door Harry Paape, Gerrold van der Stroom en David Barnouw; met de samenvatting van het rapport van het Gerechtelijk Laboratorium, opgesteld door Ir. H J.J. Hardy; tekstverzorging door David Barnouw en Gerrold van der Stroom. 's-Gravenhage Staatsuitgeverij Bert Bakker.

Rimmon-Kenan, S. 1983. Narrative fiction: Comtemporary poetics. London: Methuen.

Severijnen, O. 1989. Genre en periode: De autobiografie en het modernisme. In: Jongeneel, E. (red.) Over de aulobiografie. Utrecht : Hes Uitgevers. p. 64-81.

Van der Stroom, G. 1986a. De dagboeken, "Het Achterhuis" en de vertalingen. In: Rijksinstituut voor Oorlogsdocumentatie. De dagboeken van Amme Frank ... 's-Gravenhage : Staatsuitgeverij Bert Bakker. p. 69-90.

Van der Stroom, G. 1986b. Verantwoording van de tekstverzorging. In: Rijksinstituut voor Oorlogsdocumentatie. De daghoeken van Amme Frank ... 's-Gravenhage : Staatsuitgeverij Bert Bakker. p. 189-193.

Weintraub, K. 1989. De ontwikkeling van de autobiografie als vorm van zelfbewustwording. In: Jongeneel, E. (red.) Over de aulobiografie. Utrecht : Hes Uitgevers. p. 9-26. 
